\title{
Evaluation of Damage in DNA Molecules Resulting From Very-Low-Frequency Magnetic Fields by Using Bacterial Mutation Repairing Genetic System
}

\author{
Akira Igarashi ${ }^{1}$, Koichiro Kobayashi ${ }^{1}$, Hidetoshi Matsuki ${ }^{2}$, Member, IEEE, Ginro Endo ${ }^{3}$, and \\ Akira $\mathrm{Haga}^{3}$, Member, IEEE \\ ${ }^{1}$ Faculty of Engineering, Iwate University, Morioka 020-8551, Japan \\ ${ }^{2}$ Graduate School of Engineering, Tohoku University, Sendai 980-8579, Japan \\ ${ }^{3}$ Faculty of Engineering, Tohoku Gakuin University, Tagajo 985-8537, Japan
}

The effect of very-low-frequency magnetic fields (VLFMF) on living biological cells was investigated using a highly sensitive mutagenesis assay method. A bacterial gene expression system for mutation repair (umu system) was used for the sensitive evaluation of damage in DNA molecules. Salmonella typhimurium TA1535/pSK1002 were exposed to VLFMF $(20 \mathrm{kHz}, 600 \mu \mathrm{T}$, and $60 \mathrm{kHz}, 100 \mu \mathrm{T})$ in a specially designed magnetic field exposure chamber. The experimental results showed the possibility of applying the $u m u$ assay for sensitive and effective evaluation of damage in DNA molecules. No significant difference was observed in the umu gene expression intensity under exposure to magnetic field of $20 \mathrm{kHz}, 600 \mu \mathrm{T}$, and $60 \mathrm{kHz}, 100 \mu \mathrm{T}$.

Index Terms-Mutation repairing gene, Salmonella typhimurium TA1535/pSK1002, umu assay, very-low-frequency magnetic field (VLFMF), $\beta$-galactosidase.

\section{INTRODUCTION}

$\mathbf{E}$ LECTRIC rice cookers, microwave ovens, and induction cooking appliances are widely used in the home. In addition, electric kitchens are being introduced not only into individual houses but also restaurants, school lunch centers, hospitals, and nursing facilities, with induction cooking appliances becoming widely used. Meanwhile, the excitation frequency of induction cooking appliances is being increased from the conventional $20 \mathrm{kHz}$ to about $100 \mathrm{kHz}$ to enhance performance. However, a part of the magnetic field generated by the exciting coils is transmitted to the cooking pan and leaks around outside. As induction cooking appliances become used more widely, the risk to the general public of exposure to very-low-frequency magnetic fields (VLFMF) may have increased [1]. The effect of VLFMF on human health has not yet been completely clarified, but the public is concerned about possible effects [2].

It is well known that mutation in DNA molecules is a direct cause of cancer development, and there is a close relationship between the oncogenesis of biological cells and molecular damage to DNA. When the DNA of a bacterium is damaged, SOS repairing genetic systems such as a bacterial umu operon and a recA gene system, which try to repair the damage rapidly, are expressed. In this study, we exposed the bacterium Salmonella typhimurium TA1535/pSK1002 to VLFMF, and examined the expression intensity of the activity of $\beta$-galactosidase, which is located downstream of the umu SOS gene operon, using the umu assay method with a nonexposure control [4]. This paper describes the results of the umu analysis evaluation of damage to DNA molecules caused by VLFMF exposure with different frequencies. According to the study of Miyakoshi's experiment

Digital Object Identifier 10.1109/TMAG.2005.854837

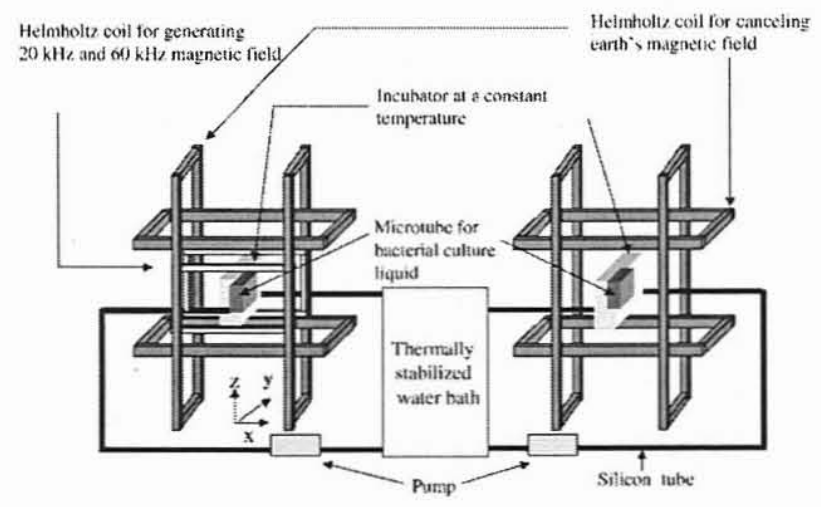

Fig. 1. Experimental system for testing bacteria DNA damage by VLFMF exposure.

with exposure of MeWo cells derived from human melanoma to a $50 \mathrm{~Hz}$ and $400 \mathrm{mT}$ magnetic field proved that the frequency of inducing mutations for HPRT genes increased in proportion to the density of the induction current in an ac magnetic field [3]. The induction current is proportional to $\mathrm{f} \times \mathrm{B}$. In our experiment, we paid attention to the induction current and set the density at $20 \mathrm{kHz}$ magnetic field of $600 \mu \mathrm{T}$ and $60 \mathrm{kHz}$ magnetic field of $100 \mu \mathrm{T}$ so that an induction current similar to that derived under the above conditions $(50 \mathrm{~Hz}$ and $400 \mathrm{mT})$ can be obtained.

\section{VLFMF EXPOSURE EQUIPMENT}

Fig. 1 shows the VLFMF exposure equipment used in this study. It consisted of Helmholtz coils for canceling the earth's magnetic field, a coil for generating the VLFMF $(20 \mathrm{kHz}$, $600 \mu \mathrm{T}$, and $60 \mathrm{kHz}, 100 \mu \mathrm{T}$ ), and a device for controlling the temperature of a bacterial culture liquid in microtubes. Eight microtubes $(3.4 \mathrm{~cm}$ in long, $1.1 \mathrm{~cm}$ in diameter) with 


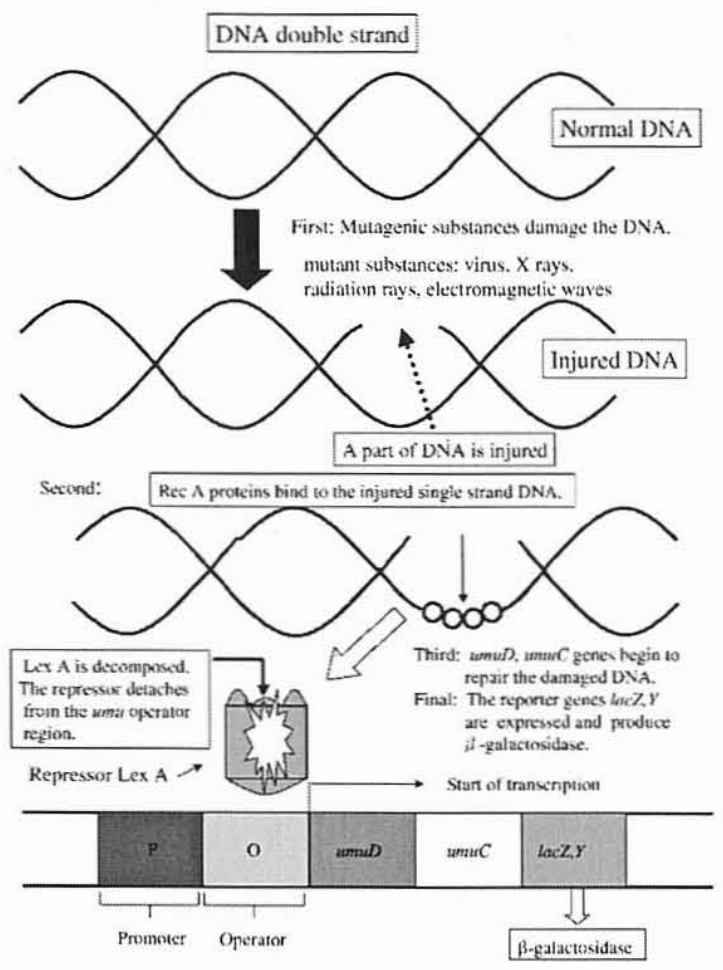

Fig. 2. The principle of $\beta$-galactosidase production by damaging a part of the DNA.

the bacterial culture were set in the incubator. The number of bacteria is about 0.15 billion/microtube. To maintain the activity of the bacterial cells, the temperature of the microtube was kept constant at $37{ }^{\circ} \mathrm{C}$. The earth's magnetic field was cancelled by a set of Helmholtz coils. Another set of Helmholtz coils was used for generating the VLFMF. The magnetic field to which the whole bacterial culture liquid in the microtubes was exposed, was $98 \%$ uniform. The temperature distribution was uniformly controlled within $37 \pm 0.1^{\circ} \mathrm{C}$ in whole bacterial culture liquid in the microtubes.

\section{Measurements of Activities of $\beta$-Galactosidase}

S. typhimurium TA1535/pSK1002 is a bacterium that has umuC, $D$ and $l a c Z, Y$ genes. If DNA-destroying substances are present, $S$. typhimurium TA1535/pSK1002 produces $\beta$-galactosidase by the gene expression of $l a c Z, Y$. The principle of this process is shown in Fig. 2. First, when mutagenic substances damage the DNA in S. typhimurium TA1535/psk1002, RecA protein binds to the injured single strand DNA. Then the bound RecA protein decomposes LexA protein, which is a repressor for the umu operon. After the repressor detaches from the $u m u$ operator region, the $u m u C, D$ genes (ultra mutant genes) begin to repair the damaged DNA. Finally, the lac $Z, Y$ genes which are placed downstream of umuC, $D$ are also expressed to produce $\beta$-galactosidase. Therefore, the degree of damage to the DNA can be evaluated quantitatively, by detecting the activities of $\beta$-galactosidase. This is called the $u m u$ assay method and was used in this study.

The measurement protocol was developed to detect damage in DNA using a mutagenic reagent and VLFMF. The $\mathrm{OD}_{420}$ and

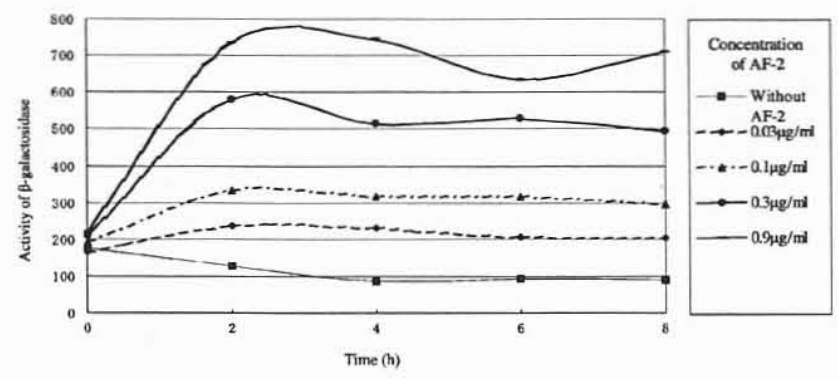

Fig. 3. Activities of $\beta$-galactosidase measured with the results of positive control tests and without AF-2.

$\mathrm{OD}_{550}$ are optical densities of optical absorbance measured at the wavelengths of 420 and $550 \mathrm{~nm}$, respectively:

The degree of activity of $\beta$-galactosidase

$$
=1000\left(O D_{420}-1.75 \cdot O D_{550}\right) /\left(\mathrm{t} \cdot \mathrm{v} \cdot O D_{600}\right)
$$

where " $\mathrm{t}$ " is reaction time (in minutes) and " $\mathrm{v}$ " is dilution rate.

To confirm the effectiveness of the test protocol developed in this study for DNA damage, furylfuramide (AF2), which is known as a strong mutagen which induces damage in DNA molecules, was used as a positive control. It was clearly recognized that the value of the activity of $\beta$-galactosidase increased as AF-2 concentration rose, as shown in Fig. 3. Therefore, the $u m u$ assay method is effective for examining the influence of environmental factors on DNA molecules.

\section{Measurements of Possible Induction DNA Damage FROM EXPOSURE TO VLFMF}

Tables I and II show the results of the $\beta$-galactosidase activity of the bacterial culture liquid exposed to VLFMF at the temperature of $37^{\circ} \mathrm{C}$ for $2 \mathrm{~h}$ and of the control bacterial culture liquid without VLFMF exposure. A Thompson rejection test was performed for each of the eight obtained data. We judged whether the eight sample data could be used and if the data at the time of exceeding a significant level was rejected. The rejected data were shown as "RD" in Tables I and II. The data adopted by Thompson rejection test were equalized, and they authorized whether a significant difference would be between magnetic field exposure and control using t-test at 5\% (rate of rejection) of significant levels. Although a significant difference was found in one time measurement (II in Table I), in view of the present results, no significant differences from exposure $20 \mathrm{kHz}$ magnetic field of $600 \mu \mathrm{T}$ and $60 \mathrm{kHz}$ magnetic field of $100 \mu \mathrm{T}$ in terms of damage in DNA molecules were observed. Because the range of "Average" \pm "Standard deviation" of data of the control and the exposure to VLFMF on DNA damage using the $u m u$ method overlap each other.

$U m u$-assay using bacteria is an established mutagen test to evaluate the mutagenic capacity of bacteria against genes, and is an official testing method widely used worldwide as a method for testing water supplies and sewage, and for evaluating the safety of drainage. This method has the important advantage of enabling a quantitative evaluation in comparison with other risks by detecting the biological effects and evaluating the safety of 
TABLE I

EXPERIMENTAL RESUlTS OF DAMAGE CAUSED to DNA MOLECULES BY EXPOSURE TO VLFMF $(20 \mathrm{KHZ}, 600 \mu \mathrm{T})$

\begin{tabular}{|c|c|c|c|c|c|}
\hline \multicolumn{3}{|c|}{$\perp$} & \multicolumn{3}{|c|}{ ـ } \\
\hline \multirow{2}{*}{ Sample number } & \multicolumn{2}{|c|}{ Activity of $\beta$-galactosidase } & \multirow{2}{*}{ Sample number } & \multicolumn{2}{|c|}{ Activity of $\beta$-galactosidase } \\
\hline & Control & Exposure & & Control & Exposure \\
\hline 1 & 253.50 & 273.11 & 1 & 260.70 & 208.33 \\
\hline 2 & 269.32 & 261.08 & 2 & 259.76 & 230.35 \\
\hline 3 & RD & 256.77 & 3 & 264.61 & 193.51 \\
\hline 4 & 257.83 & 283.15 & 4 & 248.54 & 254.68 \\
\hline 5 & 261.56 & 271.39 & 5 & 239.38 & RD \\
\hline 6 & 276.48 & 265.50 & 6 & 244.40 & 224.71 \\
\hline 7 & 282.00 & 290.69 & 7 & 263.60 & 215.54 \\
\hline 8 & 263.35 & 286.90 & 8 & 236.06 & 203.88 \\
\hline Average & 266.29 & 273.57 & Average & 252.13 & 218.71 \\
\hline Dispersion & 89.43 & 133.86 & Dispersion & 114.04 & 348.31 \\
\hline SD & 9.46 & 11.57 & SD & 10.68 & 18.66 \\
\hline significance & \multicolumn{2}{|c|}{$x$} & significance & \multicolumn{2}{|c|}{0} \\
\hline \multicolumn{3}{|c|}{ 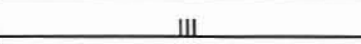 } & \multicolumn{3}{|c|}{ IV } \\
\hline Sample number & \multicolumn{2}{|c|}{ Activity of $\beta$-galactosidase } & Sample number & \multicolumn{2}{|c|}{ Activity of $\beta$-galactosidase } \\
\hline & Control & Exposure & & Control & Exposure \\
\hline 1 & 355.47 & RD & 1 & 262.78 & RD \\
\hline 2 & 393.29 & 342.34 & 2 & RD & 300.75 \\
\hline 3 & 323.70 & 324.36 & 3 & 321.84 & 300.95 \\
\hline 4 & 391.93 & 350.19 & 4 & 328.24 & 299.81 \\
\hline 5 & 372.40 & 333.98 & 5 & 348.78 & $2 \times n .23$ \\
\hline 6 & 337.74 & 364.46 & 6 & 309.25 & 274.51 \\
\hline 7 & 352.94 & 354.37 & 7 & 290.73 & 276.42 \\
\hline 8 & 397.51 & 372.24 & 8 & 301.89 & 288.97 \\
\hline Average & 365.62 & 348.85 & Average & 309.07 & 288.81 \\
\hline Dispersion & 664.85 & 240.95 & Dispersion & 662.56 & 120.38 \\
\hline SD & 25.78 & 15.52 & SD & 25.74 & 10.97 \\
\hline significance & \multicolumn{2}{|c|}{$\bar{x}$} & significance & \multicolumn{2}{|c|}{$x$} \\
\hline
\end{tabular}

$\mathrm{RD}=$ Rejected data by Thompson rejection test

VLFMF. The $u m u$ assay method was applied to evaluate the direct impact of exposure to a VLFMF on DNA damage for the first time in this study. The experimental results showed that the umu assay method could be effectively applied to the evaluation of damage in DNA molecules caused by exposure to a VLFMF. But, it is not possible from present knowledge to make a definitive statement about the safety or hazard associated with exposure to VLFMF.

It is necessary to clarify the threshold value of the significance by exposing a stronger and higher frequency magnetic field. Also, it is necessary to develop the new gene expression system by improving the bacteria having the $l u c A, B$ genes which are placed downstream of $u m u C, D$, and are expressed to emit the luminescence. The damage in DNA molecules can be evaluated by measuring the strength of luminescence.

\section{CONCLUSION}

In this study, the $u m u$ assay method, which has been used to detect DNA damage, was used to evaluate the direct impact of exposure to VLFMF on DNA destruction. The results did not reveal any damage to DNA molecules caused by exposure to magnetic field of $20 \mathrm{kHz}, 600 \mu \mathrm{T}$, and $60 \mathrm{kHz}, 100 \mu \mathrm{T}$.

TABLE II

EXPERIMENTAL RESULTS OF DAMAGE CAUSED TO DNA MOLECULES BY EXPOSURE TO VLFMF $(60 \mathrm{KHz}, 100 \mu \mathrm{T})$

\begin{tabular}{|c|c|c|c|c|c|}
\hline \multicolumn{3}{|c|}{$\mathrm{v}$} & \multicolumn{3}{|c|}{$\mathrm{Vl}$} \\
\hline \multirow[t]{2}{*}{ Sample number } & \multicolumn{2}{|c|}{ Activity of $\beta$-gahactosidase } & \multirow[t]{2}{*}{ Sample number } & \multicolumn{2}{|c|}{ Activity of $\beta$-gahactosidase } \\
\hline & Control & Exposure & & Control & Exposure \\
\hline 1 & 224.05 & 214.63 & 1 & 259.08 & 249.15 \\
\hline 2 & 224.41 & 206.56 & 2 & 243.74 & 200.87 \\
\hline 3 & 229.34 & 221.12 & 3 & 253.31 & 251.11 \\
\hline 4 & 216.45 & 224.44 & 4 & 199.48 & 194.44 \\
\hline 5 & 221.09 & RD & 5 & 256.49 & 185.87 \\
\hline 6 & $\mathrm{RD}$ & 225.49 & 6 & 208.00 & 242.52 \\
\hline 7 & 220.36 & 233.17 & 7 & 190.78 & 252.37 \\
\hline 8 & 212.79 & 223.29 & 8 & 208.00 & 248.32 \\
\hline Average & 221.21 & 221.24 & Average & 227.36 & 228.08 \\
\hline Dispersion & 25.54 & 62.01 & Dispersion & 707.74 & 729.58 \\
\hline SD & 5.05 & 7.87 & SD & 26.60 & 27.01 \\
\hline significance & \multicolumn{2}{|c|}{$x$} & significance & \multicolumn{2}{|c|}{$x$} \\
\hline \multicolumn{3}{|c|}{ Vll } & \multicolumn{3}{|c|}{ VIll } \\
\hline Sample number & \multicolumn{2}{|c|}{ Activity of B-galactosidase } & Sample number & \multicolumn{2}{|c|}{ Activily of $\beta$-galactosidase } \\
\hline & Control & Exposure & & Control & Exposure \\
\hline 1 & 261.76 & 311.83 & $\mathrm{I}$ & 300.29 & 307.60 \\
\hline 2 & 244.67 & 256.61 & 2 & 312.39 & 297.45 \\
\hline 3 & 271.51 & 302.06 & 3 & 350.69 & 287.16 \\
\hline 4 & RD & 259.26 & 4 & 325.06 & 328.12 \\
\hline 5 & 279.66 & 241.95 & 5 & 312.61 & 368.54 \\
\hline 6 & 274.27 & 313.03 & 6 & 312.43 & 374.07 \\
\hline 7 & 270.38 & 305.02 & 7 & 345.22 & 324.84 \\
\hline 8 & 234.57 & 301.81 & 8 & 331.01 & 343.12 \\
\hline Average & 262.40 & 286.45 & Average & 323.71 & 328.86 \\
\hline Dispersion & 239.21 & 723.16 & Dispersion & 271.59 & 876.95 \\
\hline SD & 15.47 & 26.89 & SD & 16.48 & 29.61 \\
\hline significance & \multicolumn{2}{|c|}{$\bar{x}$} & significance & \multicolumn{2}{|c|}{$x$} \\
\hline
\end{tabular}

$\mathrm{RD}=$ Rejected data by Thompson rejection test

\section{ACKNOWLEDGMENT}

This work was supported in part by a Grant-in-Aid for Scientific Research (B) (15360153) from the Japan Society for Promotion of Science. This paper was presented at the International Magnetics Conference (Intermag), Nagoya, Japan, April 4-8, 2005. See IEEE Trans. Magn., vol. 41, October 2005.

\section{REFERENCES}

[1] K. Kamata and A. Haga, "Measurements of magnetic fields produced by induction cooking heaters," in Proc. EMC Europe, Sep. 2004, pp. 98-103.

[2] "Present-state evaluation on the biological effect of electromagnetic field and future problems," Inst. Elect. Eng. Jpn., Biological Effect Problem Investigation Committee, 1998.

[3] J. Miyakoshi, N. Yamagishi, S. Ohtsu, K. Mohri, and H. Takebe, "Increase in hypoxanthine-guanine phosphoribosyl transferase gene mutations by exposure to high-density $50 \mathrm{~Hz}$ magnetic fields.," Mutation Res., vol. 349, pp. 109-114, 1996.

[4] Y. Oda, S. Nakamura, I. Oki, T. Kato, and H. Shinagawa, "Evaluation of the new system (umu-test) for the detection of environmental mutagens and carcinogens," Mutation Res., vol. 147, no. 5, pp. 219-29, 1985.

Manuscript received February 7, 2005. 